\title{
KERAGAMAN GENETIK BERDASARKAN KARAKTER MORFOMERIK UDANG MANTIS Marpiosquilla raphidea Fabricius, 1798 ASAL PERAIRAN INDONESIA
} Mugi Mulyono', Mufti Petala Patria², Abinawanto', Rjdwan Aflandi ${ }^{2}$ \begin{abstract}
ABSTRAK
The Harpiosquilla raphidea Fabricius _ 1798 adalah salah satu dari udang mantss penting datam Eanlen Eay yang memiki perairan characterition unlk Penelitian menyikapl Keragaman morfologi udang mants $\mathrm{H}$. raphidea dinyatakan dari perbedaan karakter ukuran tubuh ( morfomeiri ), 20 karakter rostometrik dari 22 karakies yang becbeda sangat nyata dari 2 fidak berteda nyata karakter segmen kelima rebar purut ( ASL ) dan segmen keenam ( ASN ) - Nilai terjauh jarak Banten Bay populasl adalah populasi Edinburgh . sedangkan pernduduk yang paling dekat dengan Cisebun

Kata kunci : Harplosquulita raphidea, keragaman genetik, Banten Bay, Indonesia

\section{ABSTRACT: GENETIC DIVERSITY OF MANTIS SHRIMP Harpiosquilla raphidea Fabricius, 1798 FROM BANTEN BAY AND OTHER INDONESIAN WATERS).} By Mugi Mulyono', Mufti Petala Patria ${ }^{2}$, Abinawanto ${ }^{2}$, Ridwan Affandi ${ }^{2}$

The Harpiosquila raphidea Fabricius, 1798 is one of the important mantis shrimp in Bemlen Bay lhat have unique charactertion waters. Research addressing the diversily of mutphokgy of mantis shmmp H. raphidea expossed from differences in boty size characters inorphometric), 20 mophomevic characters of 22 different characters aro very real and 2 were not significanly different character is the fifh segment of the abdonien with (ASL) atid a axth Bugnent (ASN) Value fanhest distance Banten Bay population is the poptiation of Edinbutgh, white the population closest to Cirebon.
\end{abstract}

Keywords: Harplosquilla raphidea, genetic diversity, Banten Bay, Indonesia

\section{PENDAHULUAN}

Populasi udang mantis yang cenderung menurun dapat menyebabkan berkurangnya populasi efektif yang menghasilkan peningkatan inbreeding sehingga menekan "fitness" populasi udang tersebut dan akhirnya dapat menyebabkan kepunahan. Strategi pengelolaan yang tepal diperlukan untuk menghindari kepunaharn udang mantis, untuk itu perlu dilakukan kajjan yang meliputi aspek biologi populasi dan kondisi habitat.

Identifikasi populasi dapat dilakukan melalui pengukuran karakter morfokgi dengan analisis morfometrik. Mcrfometrik yaitu perbandingan ukuran relatif bagian-bagian tubuh, sementara karakter meristik adalah bagian yang dapat dihaung dari udang yang inerupakan jumlah bagian-bagian lubuh udang. Perbedaan morfologis antar populasi depat berupa perbedaan jumlah, ukuran dan benluk (Sprent 1972). Keunggulan menggunakan karakter morfologi dalam membedakan populasi adalah mudah dilakukan, tidak memertukan biaya besar dan tidak memerlukan waktu lama (Mustafa 1999; Gustino 2003).

Ada beberapa metode untuk mengukur keraganan genetik di dalam atau antar populasi. Menurut Chambers dan Bayless (1983), ada tujuh cara untuk mengetahui keragaman genetik yaitu pengukuran asam inti, sekuensing protein, elektroforesis, Imunologi. Kromosam, hubungan antar lokus, morfometrik, dan studi breeding. Allendroff dan Phelp (1981) menyatakan bafiwa cara untuk menduga keragaman genetik populasi diamati dengan motode biometrik yaitu keragaman karakter fisiologis atau morfologis yang terukur seperti bobot panjang, umur kematangan, ketahanan lerhadap penyakit, toleransi salinitas, metode studi kromosom, dan marka genetik biokimia

1.Jakarta Fisheries University, Jakaria, 12520, Indonesia

2 Departement of Biology. Faculty of Mathematics and Natural Science; Universilas Indanesia, Lepok. 16424 , indonesia

3 Department of Aquatic Resources Management. Faculty of Fistieries and Marine Sciences, Bryor

Agricuiltural University, Kampus FPIK-IRB,Darmaga,Bogor18680, Indonesia 
Penelitian mengenai keragaman morfologi udang mantis belum banvak dilakukan. Secara umum teiah dilakukan penelitian terhadap keragarnan genetik man yaitu ikan lele (Hadie 1997) den ikan belida (Madang 1999; Witbowo 2011). Pada krustase terutama Periaeus telah dilakukan Imron (1998); Moria ef al (2002) dan Macrobracium oleh Hadie ef al. (2002). Penelitian tentang keragaman genetik berdasarkan karakter morfologi pada udang mantis di Indonesia maupun di dunia khususnya udang martis Hampiosquilla raphidea masih belum dilakukan, oleh karena tu penelitian ini dilakukan agar diketahui keragaman genetik antara populasi Teluk Banten dengan populasi di Kuala Tungkal Jarnbi, populasi di Clrebon Jawa Barat dan populasi di Pontianak Kalimantan Barat. Dalam kajian karakter morfologi akan ditemukan variasi karakter kuantitatif dan karakter yang menjadi pemberda antar populasi Harpiosquîla raphidea asal perairan Teluk Banten, Jambi, Cirebon dan Pontianak. Karakter yang digunakan mengacu pada beberapa kunci identifikasi dan hasil penelitian yang berkaitan dengan variasi karakter morfologiH. raphidea (Manning 1969; Ahyong 1997; Mori et al. 2009)

Berdasarkan pentingnya data keragaman genetik setagai upaya konservasi udang mantis H. raphidea maka dilakukan analisis morfologi. Tujuan penelitian adalah unluk mengetahui keragamen morfologi meliputi : keragaman ukuran sampel dan keragaman karakter morfologi. Hasil penelitian ini dharapkan dapat bermanfaat untuk merumuskan langkah-langkah awal dalam upaya konservasi. Upaya konservasi melalui kegiatan domestikasi dengan melakukan perkawinan silang unluk berdasarkan karakter mortometrik udang mantis $H$. raphidea.

\section{BAHAN DAN METODA}

Penelitian dilaksanakan pada bulan Desember 2011 sampai dengan Oktober 2013. Pengamatan morfornetrik udang mantis dilakukan di Laboratorium Kesehatan lkan, Sekolah Tinggi Perikanan Jakarta.

\section{Lokasi Pengambilan dan Penanganan Sampel}

Pengambilan sampel udang dilakukan pada empatpopulasi perairan yaitu Teluk Banten (Ganten), Kuala Tungkal (Janibi), Padang Tikar. Pontianak (Kalimantan Barat), tan Gebang, Cirebon (Jawa Barat). Pengambilan sampel pada masing-masing lokasi sebanyak 60 ekor. Pengambilan sampel dengan bantuar nelayan setempat menggunakan irammel net. Penentuan lokasi pengambilan sampel berdasarkan lokasi gecgrafi yang berbeda (Gambar 1).

Sampel udang mantis dari masing-masing populasi selanjutnya dikemas dalam sistem kering dengan teknik hibernasi atau dengan melakukan penurunan suhu dengan meletakan es batu dalam kemasan kardus sehingga udang mantis dalam keadaan pingsan. Seielah sampai di laboratorium kemudian diukur karakter morfometriknya.

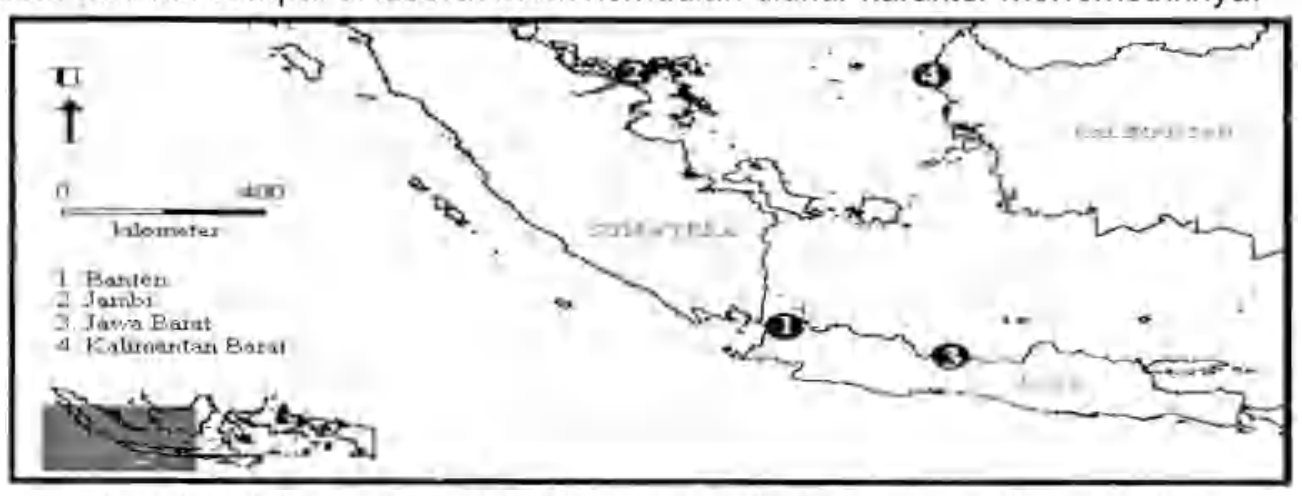

Gambar 1.Lokasi pengambilan sampel udang mantis $H$. raphidea 


\section{Metode Penelitian}

\section{Pengukuran morfologi}

Pengukuran morfologi menggunakan kaliper digital dengan ketelitian 0,01 mm, sementara untuk pengukuran bobot menggunakan timbangan O-Hous dengan ketelitian $0,1 \mathrm{~g}$. Udang mantis $H$. raphidea dikumpulkan dari perairan Teluk Banten, Jambi. Jawa barat dan Kalimantan Barat masing-masing sebanyak 60 ekor dengan kisaran panjang lotal antara $130-330 \mathrm{~mm}$. Sampel dibawa ke laboratorium untuk diidentifikasi jehis kelamin dan diukur karakter morfologinyanya.

Karakter morfologi (Gambar 2) yang diukur berdasarkan modifikasi dari penelitian Ahyong (2007), Liu el al. (2008) dan Mori et al. (2009). Untuk memudahkan dalam analisis data berdasarkan kode sampel setiap pengukuran diberikan kode asal populasi dan singkatan karakter.

Karakter morfologi yang diukur adalah panjang total (PTO), panjang standai (PST), panjang abdomen total (PAT), panjang karapas parsial (PKP), lebar karapas (LKP), panjang torak somite (PTS). Panjang abdomen somite (PAS), lebar abdomen somite (LAS), lebar abdomen somite ruas kesalu (ASS), lebar abdomen somite ruas kedua (ASD), lebar abdomen somite ruas ketiga (AST), lebar abdomen somite ruas keempat (ASE), ), lebar abdomen somite ruas kelima (ASL), lebat abdomen somite ruas keenam (ASN), panjang maxilliped II kiri (PMI), lebar menis kiri (LMI), panjang maxilleped II kanan (PMA), lebar merus kanan (LMA), panjang uropod kiri (PUI) panjang uropod kanan (PUA), panjang telson (PTL) dan lebar telson (LTL). Ringkasan karakter morfologi yang diukur dapat dilihat pada Tabel 1.

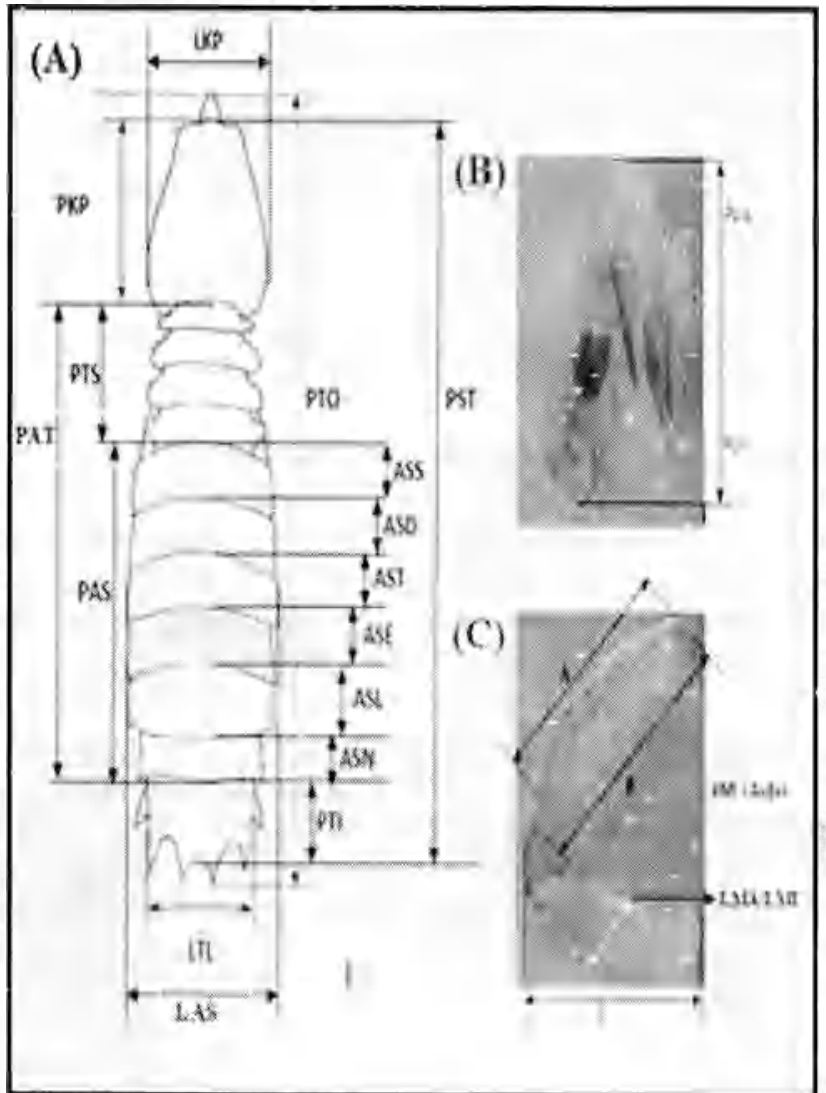

Gambar 2 Karakter morfologi udang mantis $H$. raphidea (A) Morfologi bagian atas (B) Uropod dan (C) Maxilliped II 
Tabel 1. Ringkasan karakter morfologi udang mantis $H$. raphidea yang dlukur untuk pembandingan data mortometrik (modifikasi Mori et al. 2009)

\begin{tabular}{|c|c|c|}
\hline No & Karakter & Definisi dalam pengukuran \\
\hline 1 & PTO & Panjang dari ujung telson terdalain dan ujung karapas \\
\hline 2 & PST & Panjang dari ujung telson terdalam dan ujung kacapas bagian depan \\
\hline 7 & PAT & $\begin{array}{l}\text { Panjang dari ujung bawah bagian abdomen hingga bagian bawah } \\
\text { karapas }\end{array}$ \\
\hline 4 & PKP & Panjang ujung karapas dan karapas belakang batas torak \\
\hline 5 & LKP & Lebar antara karapas paling lebar dari ujung kanan ke kiri \\
\hline 6 & PTS & Panjang antaka batas karapas ningga batas abdomen \\
\hline 7 & PA5 & $\begin{array}{l}\text { Panjang antara batas torak somite bagiar belakang hingga ujung telson } \\
\text { baglan depan }\end{array}$ \\
\hline 8 & LAS & Lebar antara abdomen somite terlebar dari ujung kanan ke kiri \\
\hline 9 & ASS & Lebar ruas abdomen somites kesatu \\
\hline 10 & ASD & Lebar ruas abdomen somites kedua \\
\hline 11 & AST & Lebar ruas abdomen somites ketiga \\
\hline 12 & ASE & Lebar ruas abdumen somites keempat \\
\hline 13 & ASL & Lebar ruas abdomen somites kelima \\
\hline 14 & ASN & Lebar ruas abdomen somites keenam \\
\hline 15 & PMI & Panjang antara ujung maxilliped hingga ujung dactylus sebelah kiri \\
\hline 16 & LMI & Lebar ruas merus kiri ujung bawah hingga bagian atas (lebar) \\
\hline 17 & PMA & Panjang antara ujung maxilliped hingga ujung dactylus sebelah kanan \\
\hline 18 & LMA & Lebar fuas merus kanan ujung Dawah hingga bagian atas (lebar) \\
\hline 19 & PUI & Panjang dari gangkal thopod hingga Ujung sebelah kiri \\
\hline 20 & PUA & Panjang dari pangkal uropod hingqu ujung sebelah kanan \\
\hline 21 & PTL & $\begin{array}{l}\text { Panjang Telson di tukur dari bagian depan telson hirgga ruas telson } \\
\text { terdalam bagian belakang }\end{array}$ \\
\hline 22 & LTL & $\begin{array}{l}\text { Lebar lelson diukur dari kedalaman terigan lelson hingga tragian atas } \\
\text { sebelum abodomen somito keenam }\end{array}$ \\
\hline
\end{tabular}

\section{Analisis Data}

Analisis dala morfometrik dengan analisis diskriminan yang digunakan untuk melihat perbedaan yang signifikan antar kelompok yang ditentukan oleh karakter morfologi yang dianati Hasil pengukuran direlatifkan dengan panjang standar untuk menghindari keragaman ukuran dan kemungkinan umur yang berbeda. Selanjutrya akan dikelompokkan karakter moriologi yang paling mencirikan perbedaan tersebut. Kornponen ini juga digunakan untuk melifat pengaruh yang paling kuat terhadap permbentukan populast. Analisis dilakukan dengan menggunakan program SAS 1997 dengan prosedur PROC.PRINCOM dan pregram SPSS versi 19 yang berdasarkan Analisis Komponen Utama (Principal Component Analysis. FCA)

Arralisis komponen utama merupakan metode statistik deskriptif yang bertujuan untuk menginterpretasikan sebagian besar informasi yang terdapat dalam suatu matriks data ke dalam bentuk graflk dan untuk mendapatkan peta penyebaran populasi serta nilai kesamaan di dalam maupun di luar kelompok. Hasil yang diperoleh ditampilkan dalam bentuk gambai dendrogram.

HASIL

Analisis Morfometrik

1. Keragaman Ukuran Sampel Udang Mantis $H$. raphidea.

Total sampel udang mantis $H$. raphideayang diperoleh dalam penelitian in berjumlah 240 ekor udarig mantis dewasa : terdiri dari 122 ekor jantan dan 118 ekor betina. Sampel udang mantis memiliki panjang total antara $135-331 \mathrm{~mm}$ dengan bobot total $87-310 \mathrm{~g}$. Panjang fotal vidang mentls jarilan berkisar antara $735 .-330 \mathrm{~mm}$, sedangkan udang 
betina berkisar antara $156-331 \mathrm{~min}$. Ukuran panjang total paling panjang ditemukan pada populasi perairan Gebang, Cirebon yaltu sebesar $331 \mathrm{~mm}$. Ukuran panjang total terkecil ditemukan pada udang mantis asat perairan Teluk Banten yaitu sebesar $135 \mathrm{~mm}$. Proporsi sampel dari segl ukuran udang mantis $H$. raphidea memenuhi kriteria dalam analisis diskriminan dalam upaya mengetahut keragaman genetik berdasarkan karakter morfologi.

Rincian perbandingan jenis kelamin populasi perairan Kuala Tungkal, Jambi terdiri atas 36 ekor jantan $(60 \%)$ dan 24 ekor betina (40\%). Populasi perairan Gebang, Cirebon terdiri atas 27 ekor jantan $(45 \%)$ dan 33 ekor betina (55\%). Populasi perairan Padang Tikar, Pontianak terdiri atas 28 ekor jantan (47\%) dan 32 ekor betina (53\%), sedangkan populasi perairan Teluk Banten terdiri atas 31 ekor jantan $(52 \%)$ dan 29 ekor betina $(48 \%)$ (Gambar 3). Hasil analisis uji-t terhadap rasia jantan dan betina pada sampel penelitian ini menunjukkan I hitung $0.35<1$ tabel 2,13, yang berarti bahwa tidak ada perbedaan jartan dan betina.

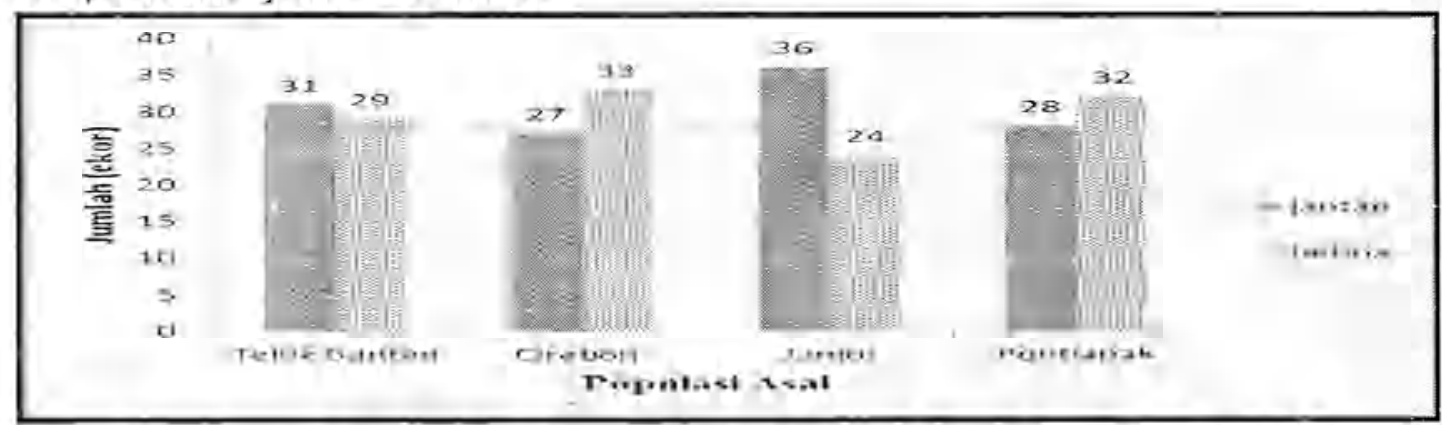

Gambar 3 Jumlah sampel udang mantis $H$. raphidea berdasarkan jenis kelamin asal empat populasi berbeda.

\section{Keragaman Morfologi Udang Mantis H. raphidea}

Hasil analisis kanonikal terhadap 22 karakter morfologi udang mantis $H$. raphidea ditunjukkan pada Tabel 2. Hasil analisis morfometrik Tabel 2, menurijukkan bahwa 2 karakter tıdak berbeda nyata $(P>0,05)$ dan 20 karakter herbeda sangat nyata $(P<0,01)$. Karakter yang tidak berbeda nyata meliputi lebar abdomen somite kelima dan lebar abdomen somite keenam.

Udang mantis H. raphidea memiliki karakter morfologi (ukuran-ukuran karapas, bobot tubuh, panjang tubuh, dan panjang ruas) beragam. Tabei 2 menunjukkan koefisien keragaman yang bervariasi pada semua poptilasi yang berbeda. Beberapa komponen terlihal tidak berbeda nyata $(P>0,05)$ antar populasi dianggap gen yang dikonservasi oleh semua populasi. Dengan kata lain. karakter tersebut dipertahankan oleh semua populasi walaupun habitainya berbeda.

Tabel 2. Karakter inorfologi udang mantis $H$. raphidea dengan analisis Canonical Discriminant Univariate Statistics

\begin{tabular}{llllllll}
\hline No. & $\begin{array}{l}\text { Karakter } \\
\text { morfometrik }\end{array}$ & $\begin{array}{l}\text { Total } \\
\text { STD }\end{array}$ & $\begin{array}{l}\text { Pooled } \\
\text { STD }\end{array}$ & $\begin{array}{l}\text { Between } \\
\text { STD }\end{array}$ & $R^{2}$ & F & Pr $>F$ \\
\hline 1 & PTO & 0,118 & 0,114 & 0,038 & 0,080 & 6,850 & 0,0002 \\
2 & PST & 0,010 & 0,020 & 0,006 & 0,269 & 29,930 & 0,0001 \\
3 & PAT & 0,082 & 0,079 & 0,026 & 0,076 & 6,500 & 0,0003 \\
4 & PKP & 0,018 & 0,010 & 0,007 & 0,139 & 12,700 & 0,0001 \\
5 & LKP & 0,045 & 0,040 & 0,021 & 0,173 & 16,510 & 0,0001 \\
6 & PTS & 0,019 & 0,010 & 0,008 & 0,135 & 12,340 & 0,0001 \\
7 & PAS & 0,016 & 0,015 & 0,005 & 0,080 & 6,880 & 0,0002 \\
8 & LAS & 0,009 & 0,007 & 0,006 & 0,342 & 41,060 & 0,0001 \\
9 & ASS & 0,005 & 0,004 & 0,003 & 0,368 & 45,830 & 0,0001 \\
\hline
\end{tabular}




\begin{tabular}{|c|c|c|c|c|c|c|c|c|}
\hline 10 & $\overline{\mathrm{ASD}}$ & 0,005 & 0,003 & 0,002 & 0.265 & 28,500 & 0,0001 & $=$ \\
\hline 11 & AST & $D_{1} 003$ & 0,002 & 0,003 & 0.293 & 32,610 & 0.0001 & - \\
\hline 12 & ASE & 0,003 & 0,003 & 0,003 & 0.275 & 29,930 & 0,0001 & $r$ \\
\hline 13 & ASL & 0,001 & 0,001 & 0,000 & 0,009 & 0,740 & 0,5271 & $v$ \\
\hline 14 & ASN & 0,001 & 0,001 & 0,000 & 0.004 & 0,330 & 0,8013 & $v$ \\
\hline 15 & PMI & 0,033 & 0,020 & 0,025 & 0,443 & 62,720 & 0,0001 & $i$ \\
\hline 16 & LMI & 0,029 & 0,020 & 0,014 & 0,176 & 16,720 & 0,0001 & * \\
\hline 17 & PMA & 0,033 & 0,012 & 0,024 & 0.417 & 56,430 & 0,0001 & s \\
\hline 18 & LMA & 0,029 & 0,012 & 0,015 & 0.209 & 20,870 & 0,0001 & * \\
\hline 19 & PUI & 0,013 & 0,012 & 0,009 & 0,393 & 51,070 & 0,0001 & n \\
\hline 20 & PUA & 0,015 & 0,012 & 0,010 & 0.331 & 38,980 & 0.0001 & 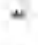 \\
\hline 21 & PTL & 0,010 & 0,020 & 0,003 & 0.070 & 5,930 & 0,0006 & $r$ \\
\hline 22 & LTL & 0,033 & 0,012 & 0,033 & 0.741 & 226,4 & 0.0001 & * \\
\hline
\end{tabular}

Keeratan semua karakter morfologi antar populasi yang diteliti lebih nyata dengan menggunakan sharing component morfometrik antar daerah sampel. Pendugaan sharing component atau nilai kesamaan (Index of similarity) antar populasi dilakukan dengan menggunakan hasil analisis diskriminan berdasarkan kesamaan ukuran tubuh tertentu (Tabel 1.3).

Tabel 3. Nilai percampuran fenotipe dalam dan antar populasi (\%) udang mantis yang menunjukkan sharing component antar populas!

\begin{tabular}{llllll}
\hline Populasi & $\begin{array}{l}\text { Teluk } \\
\text { Banten }\end{array}$ & Jambi & Cirebon & Pontianak & $\begin{array}{c}\text { Total } \\
(\%)\end{array}$ \\
\hline Teluk Banten & 85,00 & 8,33 & 3,33 & 5,00 & 100 \\
Jambi & 5,00 & 95,00 & 0,00 & 0,00 & 100 \\
Cirnbon & 0,00 & 0,00 & 98,33 & 1,67 & 100 \\
Pantianak & 8,33 & 0,00 & 1,67 & 90,00 & 100 \\
Persen & $\mathbf{2 5 , 8 3}$ & $\mathbf{2 5 , 8 3}$ & $\mathbf{2 3 , 7 5}$ & $\mathbf{2 5 , 5 8}$ & 100 \\
\hline
\end{tabular}

Kesamaan ukuran tubuh dalam kelompok yang paling besar dalam populasi adalah pada populasi udang mantis $H$. raphidea asal perairan Cirebon $(98,33 \%$,$) ; dan di$ antara populasi adalah $1,67 \%$ sharing dengan populasi Pontianak. Keragaman dalam populasi Teluk Banten adalah sebesar $85 \%$, seuangkan sharing dengan Jambi $8,33 \%$, shanng dengan Cirebon $3,33 \%$ dan sharing dengan Pontianak 5,00\%. Populasi Jambi mempunyai keragaman dalam populasi $95,00 \%$ dan sharihg dengan Teluk Banten $5,00 \%$ - Sementara nilai keragaman dalam populasi Pontianak $90,00 \%$; sharing antara populasi udang mantis $H$. raphidea asal Teluk Banten sebesar $8,33 \%$ dan sharing dengan populasi Cirebion sebesar $1,67 \%$

\section{Penyebaran Fenotipe dan Jarak Genetik Berdasarkan Karakter Morfologi}

HasilSabaran fenotipe memperlihatkan bahwa karakter morfologi udang mantis $H$. raphidea dari populasi Teluk Banten mengumpul dengan populasi Cireban pada daeral bawah garis axis $X$ dan sebelah kin garis axis $Y$, Secara umum individu keempat populasi udang mantıs $H$. raphidea menunjukkan hubungan kekerabatan antai populasi yang berbeda-beda, udang mantis $H$. raphides Teluk Bantenmempunyai hubungan cukup erat antara satu dengan lainnya. Hal ini ditunjukkan dengan adariya daerah bersinggungan dari udang mantis $H$ raphidea yang diamati di populasi Teluk Banten dengan populasi Jambs. Pontianak dan Cirebon, akan tetapi tiga populasi lainnya tidak saling bersinggungan (Gambar 1.4.), Group cenroids dari keempat populasi udang mantis $H$. raphidea berada berbeda di area sekitar garis nol dari axis $X$ dan $Y$ 


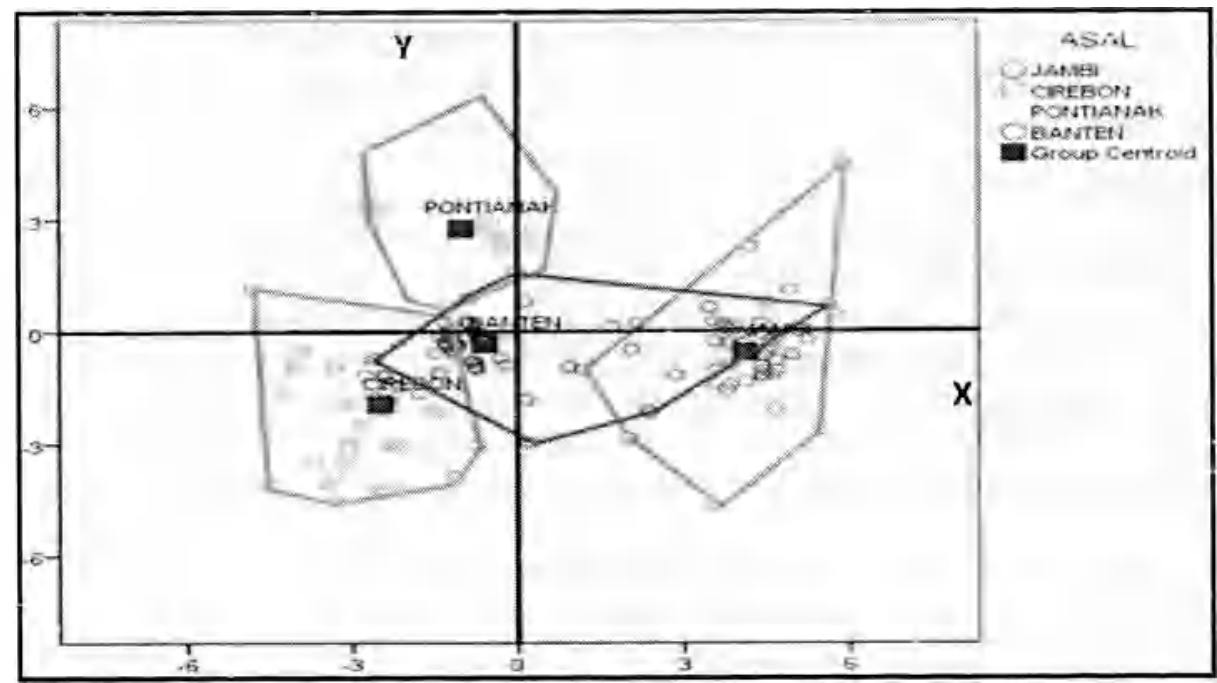

Gambar 4. Distribusi populasi udang mantis $H$. raphicea empat populasi berdasarkan pengamatan morfometrik dengan mengunakan analisis PCA

Hasil analisis PCA karakter morfologi udang mantis $H$. raphidea dengan pendekatan mahalonobis diperoleh nilai matrik jarak genetik (Tabel4). Kekerabatan terjauh adalah udang mantis $H$. raphidea populasi Teluk Banten dan Jambi sebesar 52.53, diikuti dengan populasi Cirebon dengan Teluk Banten sebesar 38,44 dan populasi Teluk Banten dengan Pontianak sebesar 17,65, sedangkan secara umum populasi yang terdekat adalah Pontianak dengan Cirebon yaitu 16,55.

Tabel 4. Matrik jarak genetik antar kelompok daerah sampel yang menunjukkan hubungan kekerabatan antar populasi udang mantis $H$, raphidea

\begin{tabular}{lllll}
\hline Populasi & Teluk Banten & Jambi & Cirebon & Pontianak \\
\hline Teluk Banten & 0 & 52,53 & 39,44 & 27,18 \\
Jambi & 52,53 & 0 & 25,08 & 17,65 \\
Cirebon & 39,44 & 25,08 & 0 & 16,55 \\
Pontianak & 27,18 & 17,65 & 16,55 & 0 \\
\hline
\end{tabular}

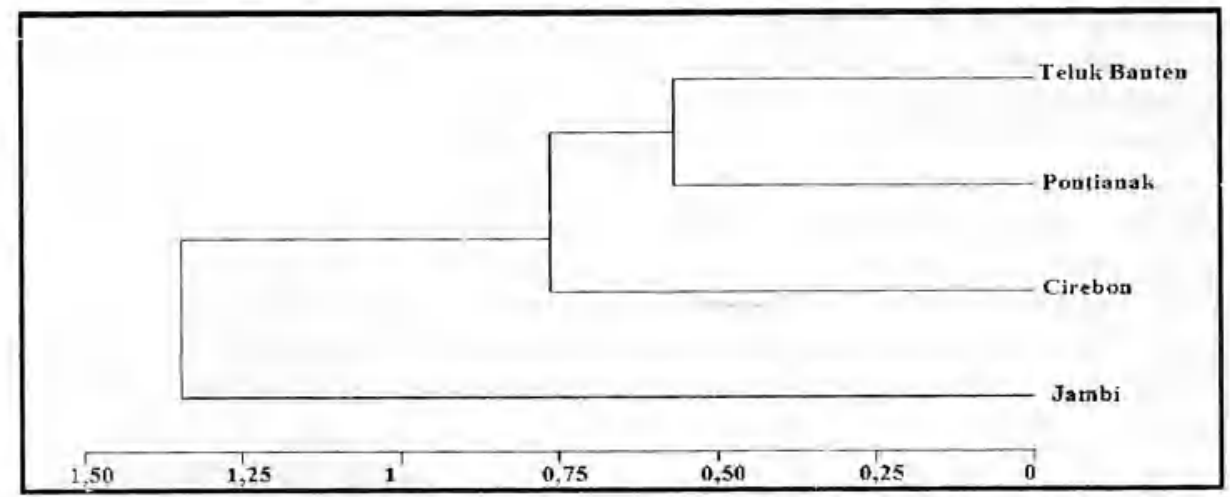

Gambar 5. Dendrogram jarak genetik udang mantis $H$. raphidea dari Teluk Banten, Pontianak, Cirebon, dan Jambi.

Dalam bentuk dendrogram, kekerabatan keempat populasi udang mantis tersebut digambarkan dalam tiga kluster utama. Udang mantis Teluk Banten dan Pontianak 
menjadi satu kelompok, dua kelompok lain masing masing adalah kelompok Cirebon dan helomock Jambi (Gambar 5).

\section{A. PEMBAHASAN}

\section{Anallsis Morfometrik}

Berdasarkan tân kelamin sampel yang dlgunakan dalam analisis morfonetrik lidak terdapat perbedaan. sehingga sampel pada penelitian in baik untuk analisis morfometrik. Analisis morfometrik adalah cara sederhana dapat digunakan untuk mengetahul keragaman genetik, dengan menghitung karakter-karakter morfologi. Perbedgan karakter-karakter morfologi sangat dipengaruhi oleh variasi ukuran sampel dan jenis kelamin. Mori et.al (2009), mengemukkan hasil penelitiannya pada udang manils Rissowdes pallidusjantan dan betina, batwa terdapal perbedaan yang sigrifikan dalam hal ukuran parjang karapas, ruas aboomen dan telson. Penelitian udang lain seperti pada udang-udang penaeld menyatakan bahwa ukurar udang menyumbang proporsi terbesar karena mengingal ukutan udang berkaitan dengan pertumbuhan (Fahman, 2012; Kusrini, 2008; Imron, 1998). Karakteristik sampel dalam Denelitian ini mernenuhi kriteria untuk analisis morlormettik.

Udang mantis $H$. raphidea memiliki karakter mortologi melalul beberapa pengukuran karakter morfologi dapat memperlihatkan bentuk tunggal untuk deskriptif selanijutnya rata-tata ukuran dalam sampel dan variasi bentuk atau disebut data moriometrik (Tabel I. 2), menunjukan koefisien keragaman yang barvariasi peria populasi yang berbeda. Hanya dua komponen atau karakter morfologi yang terlitiar tdak berbeda nyata $(P>0,05)$ antar populasi dianggap gen yang dikonservasi dieh semua populasi. Dangan kata lain, karakter morfologi tergebul dipertahankan oleh semua populasi walaupun habitatnya berbeda. Samentata 20 karakter morfologi dapat dijadikan pembeda dalam morfoimatrik yang difujukan dengan perbedaan sangat nyata $\langle<0,01)$ - Hasil analisis morfometrik merupakan cara estumasi morfologi tubuh yang penting untuk membedakan populasi udang mantis H. raphides di Indanesia Bagian Barat Perbedaaan populasi ini imungkin leijati sebagal adaptasi lokal, respon lerhadap proses seleksi. isolasi jarak dan gentefic drift alaupun faktor sejarah (Hartl \& Crark 1989).

Kesamaan morfologi seperti yang disaj|kan pada Tabel I.3 menunjukkan adanya pencampuran (sharing component) yang lenkur antara populasi satu dengan yang lainnya. Nila pencamipuran fernotip udang mantis $H$ raphidea dalam populasi $80,00-$ $98,33 \%$ dan antar populasi $1,67-8,33 \%$. Nilai pencampuran fenotip sangal berbeda dengan udang-udang lain. Hasil penefirian terhadap udang galah dari tiga populasi alam didapalkan nilai percampuran fenotipe dalam populasi berkisar $68,33 \%$-90,00\% sedang antar populasi $5,00 \%-26.67 \%$ (Hadie st al, 2002). Nilai percampuran fenolupe udang Windu dalam populasi $40,9 \%-82,2 \%$ dan antar populasi $0,0 \%-27,4 \%$ (Sulaemant et al. 2002 dalam Parenrengi et al 2007) Sedangkan pada udang pama (Penaeus semiscilcalus) nila percampuran fenotipe dalam populasi ferkisar $67,8 \%-93,1 \%$ dan antar populasi $0,0 \%-30,5 \%$ (Parenrengi ot at. 2007). Persamaan ukuran variabel merubakan gejala percampuran attat masing-masing daerah melalui percampuran gen di masa lalu. Nilai kesamaan ukuran ubuh memberikan penjelasan adanya komponen yang meruprakan sifat yang dipertahankan atau dibagikan sewaktu terjadi aliran gen (gene flow).

Beberapa karakter dapat digunakan untuk menentukan morfometrik adalah ukuran tubuh yang mempunyal nilai desimal (Leary 19B5). Peniyebaran karakter udang mantis menurjukkan bahwa populasi Jambi dan Pontianak terpisah dengari populasi Cirebon. Populasi yang paling luas penyebarannya adalah populasi Banten. Hal tersebut sẹsual dengan sharing component yang dimilikinya dimana populasi Taluk Banten mempunyai keragaman antar populasi terbesar Menurut Hadie (1997) penyebaran udang biasanya dibagr ke dalam bebełapa populasi dan dengan berjalannya waktu, populasi ladi ternesah oleh beberapa faktor geografi $k a$ dalam populasi yang terisolasi 
dan șeliap populasi mungkin mernbentuk karakter yang berbeda, yang akhirnya dapat mernbedakan populasi satu dengan yang lainnya. Penelitian karakter morfologi seperti morfometrik udang mantis dapat digunakan sebagai penande, Mentirut suparyanto et al. (1999) kedekatan kelompok ditunjukan dengan singgungan antar sarnpel.

Matriks jarak genetik antar populasi dalam Tabel 1.4. merupakan dasar pengelompokkan dalam penggambaran dendogram Nilai jarak genetik terjauh dimiliki populasi Teluk Banten-Jambi, sedangkan yang terdekat adalah populasi CirebonPontianak Nilai jarak genetik dapat digunakan sebagai acuan dalarn persilangan antar populasi. Jika perkawinan dilakukan yang hubungan kekerabatanny dapal meningkatkan keragaman secara nyata dibandingkan dengan yang mempunyai kekerabatan dekat Hal tersebut dikarenakan heterosisnya hanya borašal dari kelompoknya saja, sedangkan untuk kekerabatan yang jauh dapat diperoleh keragaman darl keduanya (Suparyanto el ail 1999).

Dendogram hasil analisis morfornetrik memperlihalkan 3 kelompok (cluster). Perigelompokan lersebut kemungkinan disebabkan oleh persamaan geografi Hal ini sesuai dengan pendapat (Tave, 1995) yang menyalakan bahwa penampilan fenotipe sangat dipengaruhi oleh habitatnya dan fenotipe suatu individu mejupakan ekspresi dari genótipe dan lingkungan.

Prosedur leknik pengukuran morfometrk memperlinatkan bentuk tunggal uniuk deskriplif selanjutnya dengan rata-rata ukuran dalam sampel dan variasi bentuk. Hartl dan Clark (1989) menguji keragaman sehubungan dengan jarak geografis organisme perairan bahwa populasi yang jauh, tesar kemungkinan uftuk berbeda, bermutasi, dan terseleksı Seleksi dan perrulusan aliran gen sama pentingnya dengan memacu perbedaan morfologi dalam populasi yang terisolassi.

\section{KESIMPULAN}

Keragaman morfologi udang mantis ( $H$. raphidea) yang terekspresi dari perbedaan karakter ukuran tubuh (morfometrik), dar 22 karakter morfometrik 20 karakter berbeda sangat nyata dan 2 karakter yang tidak berbeda nyata yaitu lebar abdomen ruas kelitne (ASL) dan nus keenam (ASN). Penyebaran fenotipe berdasarkan analisis diakriminan pada empit populasi (Teluk Banten, Cirebon, Pontianak dan Jambi) menunjukkan adarya daerah yang bersinggungan. Berdasarkan jarak genetik analisis morfometrik populasi Teluk Banten berkerabat jauh dengan populasi Jambi.

Popilasi udang mantis asal perairan Teluk Banten dapat dijadikan sebagai selective breeding upaya konservasi pada kegiatan domestikasi lebih lanjut Sebagal upaya konsarvasi dalam kegiatan domestikasi dapat dilakukan kawin silang antar populasi udang mantis Teluk Banten baik dengan populasi Jambi berdasarkan jarak genetiknya.

\section{DAFTAR PUSTAKA}

Ahyong. S.T \& C. Harling. 2000. The phylogeny of the stomatopod Crustacea. Australian doumal of Zoology $48(6): 607-642$

Anyong. S.T., T.Y. Chan \& Y.C. Liao, 2008. A Catalog of The Mantis Shrimps (Stomatepoda) of Taiwan. National Taiwan Ocean University, Keelung: vif + $190 \mathrm{hlm}$

Chambers, S.M. \& J.W.Bayless. 1983. Systematic. conservation and the measurement of genetic diversity. Cummings Publishing Company Inc. New York: $87 \mathrm{him}$

Ferguson, A J B, P Taggart, A Prodohi, O Mc Meel. C. Thompson, C Stone, Mc. Ginnity \& R.A. Hynes. 1995. The Application markers to the study \& conservation of fish population with special referens to salmon. Joumal Fisheries Biology 47:103-126.

Frankham, R. 1999 Quantitative genetic in conservation biology. Genetic Resource and Conservasion 74 237-244 
Gusfine R. 2003. Taxonomy and phylogeny of Pangasuidae catish firum Asia (Ostariaphysi, Silunifumes). Dissertation For The Doctor's Degree Katholieke Universiteit Leuven, Belgium: xix +201 him

Hadie, W. 1997. Studi Morfometrik dan Keragaman Genetika pada Populasi Ikan Lele (Clarias batrachus) di Sungai Musi dan Bengaiwan Solo. Tesis. Program Studi Biologi, Universitas indonesia: $x \mathrm{il}+64 \mathrm{him}$

Hade, W. K. Sumantadinata, O. Carman, \& L,E, Hadie. 2002. Pendugaan jarak genetik populasi udang galah (Macrobrachium rosenbergii) dari Sungai Musi, Sungai Kapuas, dan Sungai Citanduy dengan Truss morphomotric untuk menduking program pemuliaan. Jurnal Penenelitian Perikanan Indonesla8: 1-7.

Harlt, D.L. \& A. G Clark 1989 . Principle of Population Genetics. Second edition $682 \mathrm{hlm}$

Kusrini. E. 2008 Diferensiasi Genetik Udang Jerbung di Indonesia. Tesis. Program Pascasarjana inslitut pertanian Bogor: xv $+69 \mathrm{hlm}$

Leary, R.F. F.W Allendorf \& KL. Knudsen. 1985. Development instability and high meristic counts in interspesific hybrid of saimonid fishes. Evolution39: 1,318-1,326.

Lii KKY 2005 Ecology of commercialy important stomatopods in Hongkong. Thesis. The University of Hongkong. Hongkong. $x i x+258 \mathrm{hlm}$

Madang, K. 1999. Mortologi, habitat dan keragamana genetic kerabat ikan belida (Matacopterygii) di perairan Sumatera Selatan. Tesis. Institut Pertanian Bogor. 123 him

Marining. R.B. 1969, A review of the genus Harpiosquilla (Crustacea. Stomatopodg) with description of three new spexies. Smithsonian Contribution of zoology. Smithsonian Instilution Press. City of Washington: $41 \mathrm{him}$

Manning. R.E 1995. Stomatonoda crustacea of Vietnam the legacy of Racul Serene. Crustacea resealch $4.1-339$

Mari. M. M. Mura \& S. De-Ranieri 2009. Sexual Dimorphism Risssoides pallidus (Giestorecht) (Crustacea, Stomatopoda) Thalassia Salentina32: 63--71

Mona, S,B., Haryanti, IG.N. Permana \& K Sugama. 2002. Marka genetik untuk variabilitas pertumbuhan udang windu, Penasus monodon dari sumber induk terbeda melalui analisis mi-DNA-RFLP Jumal Penellitian Penikanan Inctonesia8: 1g.

Moria, S,B, Haryanti, K. Sugania \& IG,N. Permana 2002. Variasi genetik induk udang windu, Pertaeus monodon melalui analisa RAPD (Random aplification polymorphism DNA). Jurnai Ilmu-llmu Perairan dan Perikanan Indonesia9: 29-33.

Parenrengi, A. Sulaeman, W. Hadie, \& A. Tentulo. 2007. Keragaman morfologi udang pama (Penaeus semisuicaatus) dari perairan Sulawesi Selatan dan Sulawesi Tenggara. Jumal Riset Akuakultur2(1), 27-32.

Soelistyawati, D.T. 1996. Genetika Populasi Jurusan Budidaya Perikanan. Fakultas Perikanan, Institut Peitanian Bogor: $55 \mathrm{hlm}$

Soewardi, K, 2007 . Pengelolaan Keragaman Genetik Sumberdaya Perikanan dan Kelautan. Institut Pertanian Bogor: $153 \mathrm{hlm}$

Sprent, $P, 1972$, The mathematics of size and shape. Biometric 28: 23--37

Sumantadinata, K. 1980. Comparison of electrophoretic alelle frequences and genetic variability of common carp stocks from Indonesia and Japan. Aquaculture88: 263271.

Suparyanto, A , T. Purwadaria \&Subandriyo. 1999. Pendugaan jarak genetik dan faktor peubah pembeda bangsa dari kelompok domba di Indonesia melalui pendekatan analisis morfologi. Jumal IImu Temak dan Veteriner 4: 80--87 


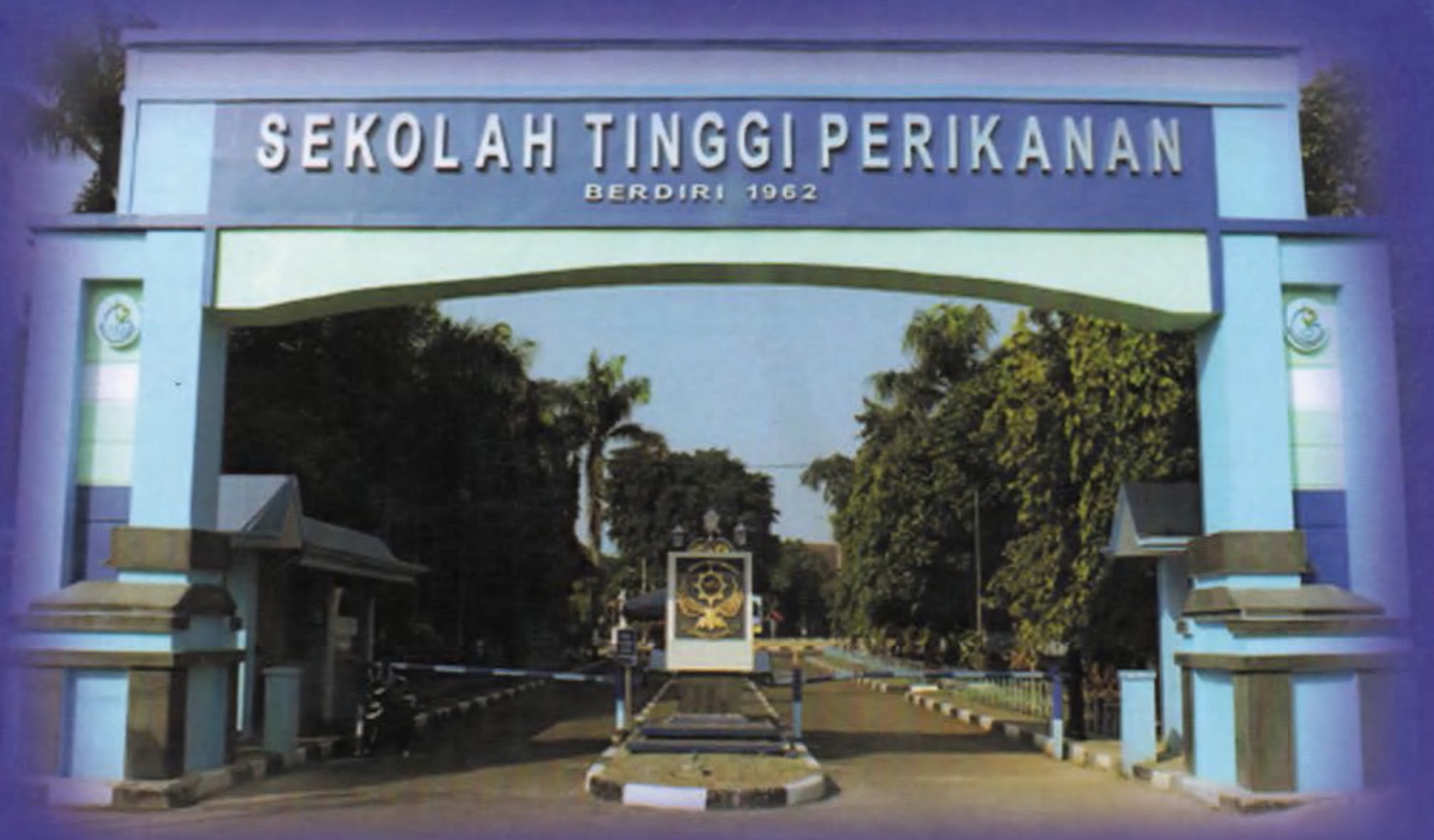

SEKOLAH TINGGI PERIKANAN JAKARTA JL. AUP PO.BOX 7239 JKPSM Pasar Minggu Jakarta Selatan, 12520 Indonesia Telp./Fax : (021) 7805030 